\title{
A regional overview, understanding the changing face of Marlborough
}

\author{
K. LOE \\ Farmer, Marlborough \\ loe.homestead@ts.co.nz
}

(Regional overview, presented at Blenheim, October 2008 - see Vol 70).

This paper gives a local perspective of the changing face of Marlborough, and the need for innovation and adoption of new technologies, opportunities, methods and practices to create a future that we all want to be part of.

President John and visitors, welcome to sunny Marlborough. I have been given a topic to open this conference and have taken the opportunity and used a little licence!

This paper gives a brief history and some of the major changes and adaptations Marlborough has made along the way, to where it is today.

\section{First a look back at where we began}

Pre-European this was classic shrub and bushland with gullies full of totaras. For the Maoris it was a food basket with an abundance of Moa and wild fowl in the wet lands.

Many fires over a long period, saw this landscape become open tussock grassland. It was this land being discussed in Barrett's hotel Wellington in 1843, that led Frederick Weld and Charles Clifford to establish the South Island's first sheep station 'Flaxbourne' in 1846 , occupying 26,700 ha $(66,000$ acres) located to the south of the salt works. They began with a flock of 3000 merinos from Australia that were unloaded in Port Underwood. 'Flaxbourne' at its peak ran 76,000 merino sheep. Shortly after 'Flaxbourne', 'Starborough' was established to the north in the Awatere, and so began the uptake of grazing runs in Marlborough.

In those early years station incomes were solely derived from wool and the rendering down of tallow. Later, skins provided an income firstly sheep then rabbits, turning a problem into an opportunity. Rabbits brought in to help the English feel at home, were present in the 1840s. They were ideally suited to the short dry grass and so adapted and multiplied quickly in Marlborough. By the 1880s, rabbit numbers had increased dramatically reaching plague proportions by the 1890s. A flourishing fur trade had built up in the South Island and by 1894 more than 17 million skins had been exported. Later, trade in canned rabbit meat also prospered.

The turn of the 20th Century saw the introduction of refrigerated ships and the birth of a flourishing meat industry. Also, at that time, pastoral leases were cut up into smaller blocks for land settlement and new communities created. Oats, barley and peas were cropped. It is said that many of the farms, particularly in the Awatere, were paid for with the profits from barley. Oats were grown largely to feed the horses that worked the ground to grow the crops. A similarity with today is that the crops are grown to produce bio-fuels to feed the machines that help grow the bio-fuels.

World War II Britain had become aware of the need for linen producers. In 1939 Britain requested New Zealand and Australia to begin producing and milling flax. New Zealand responded and in the following years many thousands of hectares were grown and milled in both Marlborough and Canterbury. At the end of the war, all the Marlborough flax processing factories closed owing to low demand and increased pressure from cotton. This brought to an end an industry which for 5 years employed large numbers of staff labouring in the sweltering heat and choking dust of its mills.

Dairying emerged to supply a growing town and in the outlying areas the cream was separated and transported to Blenheim's cheese factory.

Then there was the 1951 wool boom that really gave pastoral farming, particularly in the valleys and hills, a shot in the arm.

Marlborough was always a great lucerne growing area and a lucerne pelleting factory thrived in Blenheim for many years. The Awatere and particularly the Grassmere areas, are the best for seed production with Doug Avery's father Graham "the king of lucerne".

The Wairau plains started to diversify into pip and stone fruits, the notable one being cherries. Talleys, with processed table peas and sweet corn, found these crops offered better returns and some double cropping was possible, and the necessity for irrigation.

The 1970 s to early 80 s were noted for Government subsidies, which encouraged production of marginal lands. Of particular note here was the large area of the Marlborough Sounds, already reverted to bush and scrubland, which was brought back into pasture only to revert again or be converted to forestry, as forestry began taking over pastoral hill country, especially in the upper Wairau and the Marlborough Sounds.

Many farmers in the Sounds, loving where they lived, turned their hands to aquaculture in the early to mid $70 \mathrm{~s}$ and so the green lipped mussel industry began. 
1973 saw the beginning of the march of viticulture when Montana came to town and purchased 1000 ha. This has now grown to 22,000 ha in 2008, putting Marlborough on the world stage, with grape vines producing high quality wine on land that once finished lambs, grew crops, grain or small seeds.

Then another minor boom for the finer wool, at a time when meat returns were low, saw a rapid reduction in the average micron of wool produced in Marlborough and a shift back to merinos, as we endeavoured to go for gold.

The meat industry ebbed and flowed. Marlborough being early producing country has always received a premium for pre-Christmas export lambs. When the freezing works at Picton became a little old and tired, there was still enough stock, faith, and Marlborough was central enough, to build another at Riverlands. This has now shut down.

Marlborough hill country has always been noted for its healthy climate and ability to grow quality stock. The Wairau Plains was great finishing country to the breeding lands behind.

With diminishing finishing land, many previously store-farms reduced breeding stock in an attempt to finish their own, so further reducing breeding numbers and lambs available for export.

Oh yes and we've had our say in national issues too; we helped get rid of the Meat and Wool Boards that were much maligned for squandering our levies and the members drinking too much whisky.

\section{So where are we and where are we going in the pastoral sector?}

The sun still shines, the wind still blows and the grass grows a little less. Marlborough is still a wonderful place to live, droughts and all. Meat processing plants are gone.

The weekly sale is but a shadow of the past. The sheep and cattle numbers have given way to viticulture, forestry to lifestyle and marginal lands have simply reverted. One such marginal farm in the outer Sounds now derives its income from tourism and carbon swaps with Grove Mill wines as off-sets for their carbon zero status.

Has anyone said that Marlborough is the poorer for all this change? The diversity in this small province is huge and healthy. I believe it's onwards and upwards, change is not new. Adapt or perish. Newton's Theory, "Every force has an equal force in the opposite direction." Supply and demand is still has the greatest influence on price, and niche marketing is largely treated as a great idea for someone else to do.

Understanding climate change (science or religion) and the aims of the environmental lobby is needed.
The food safety issues and the current recession, may spell disaster and a huge disruption to our industry as we know it, or could be our opportunity to seize the moment and take charge of our destiny and lead from the front. The world still needs to housed, fed and clothed.

The sheep and beef industries are at a cross-road and if they are to thrive and grow we need leadership and vision. We are currently held to ransom by supermarket chains, and backed into corners by environmentalists, animal rights activists and our own infighting and "dog eat dog" attitudes. We won't win by fighting back we are simply outnumbered. We must lead the debate at their end and bring it back to the farm gate.

Most people vote with their wallets and they need to clearly know the cost implications to their choices, along with reasons why or why not. I have been to Europe three times in the last 5 years and have noticed big changes in attitudes of both farmers and consumers. The food miles argument and carbon footprint are at the forefront every day, as is the questioning of how it's done down on the farm and calls to do it better.

I heard on radio the following statement: "Why do farmers always put their gateways in the muddy patches"? I also heard a supposedly reputable scientist calling for people to stop eating meat to save the planet as it is an inefficient conversion of food that could be available in other forms. (His planet was clearly a flat one).

I was on a farm in Wales where the farmer had received a grant to build a new shed to house his beef cattle in winter. This policy, put in place by the environmental lobby, was to stop pugging on the hill country in winter. On the one hand they've stopped the winter pugging (and it rained every day while I was there in summer) and on the other, they now have to grow crops to cut and carry to feed the cattle!

I also noted though, a big change in farmer attitudes. They are working in more harmony and embracing their city cousins and they no longer see the NZ farmer as enemy number one, realising we need to work together or we lose together. A bit like the All Blacks, we are not seen so much as the threat we once were. Information is global and we have rested on our laurels.

I mentioned earlier that we got rid of those whiskey drinkers on the Meat and Wool Boards (yes, I helped). They received our levies to set the rules of the game, open pathways and promote our products to the world and at the same time, act as gate-keepers. Back then the agriculture minister was about number three in cabinet. We had the MAF and Economic Service giving free information and advice to farmers. We also had well-funded research and development, with the DSIR, Ruakura and world-leading research farms attached to our agricultural universities. 
I liken the removal of the Meat and Wool Boards to the removal of the cane in schools -very good arguments as to why they should go but what have we replaced them with? Or like the All Blacks moving from an amateur sport to a professional one! All focusing on short term contracts to extract as much as we can without a long term game plan, and we have separate organisations for every job or eventuality, and then another one to audit the job so they can say they have done it right and safely.

Do we really need all of these organisations? MAF (Ministry of Agriculture \& Fisheries), AHB (Animal Health Board), ERMA, Biosecurity NZ, Agriquality, Assure, NAIT (National Animal Identification \& Traceability) all meddling and having a say. The current EID (Electronic Identification) debate is a classic. It's been going on since 1997 and still not much further ahead, some $\$ 7 \mathrm{~m}$ later I'm told, and they still completely miss the point and the opportunity. As do Federated Farmers!

Meanwhile,Australia is well underway with individual electronic animal identification for cattle and soon will be doing the same for sheep; in Canada and the United States these changes are also gathering momentum. The EU and UK have announced they are to begin next year. I illustrate this as being symptomatic of how we are losing our place as leaders in agriculture. We move too slowly for fear of getting it wrong. Australia is sneaking in front as they subsidise the uptake of knowledge and technology. In 2000 I attended, along with four other New Zealanders, a Rabobank EDPP (Executive Development Programme for Primary Producers) course in Sydney, at a personal cost of $\$ 14,000$. It was worth every penny that I paid. The twenty Australians on the course had $60 \%$ of their fees subsidised. I believe this subsidy has now increased to $75 \%$.

\section{How do we progress to the next level?}

When John Peter approached Doug Avery for support as to "what are we going to do about this man-made desert we are creating", this being the catalyst to the formation of the Starborough/Flaxbourne Soil Conservation Group, he knew his master stroke was the selection of the Avery's. Not only did they live in the centre of the visible problem, but he knew they would pick it up with passion and energy. I've enjoyed being part of this group. I recount the path and success of this focus group. There has been good leadership many willing participants and supporters adding there pennies worth and to all of those, we are appreciative of the value added.

But if I pick three things as standouts as I look back they would be, starting at number 3 :

- an almost total scepticism or apathy on the part of local farmers at the beginning

- the work got done. The plants were planted, the fences top notch and the implementation of the plan was never late

But the most significant thing for me was clearly the bottom line:

- both profit and production increased

We were working with a farm already near the top of the tree and yet the Avery's improved their bottom line by $30 \%$ when the rest of us were going backwards by $30 \%$ and sheep incomes were at the lowest for 50 years. This result needs to be shouted aloud from the tops of the hills and smoke signals sent.

\section{How did this happen?}

Through monitoring, measuring and analysis the Avery's discovered and mitigated the weak points and accentuated the strong. Very little had anything to do with protecting soils, but they are proud farmers and responsible stewards, that have created an income and spent way more than most on protecting the soil and thereby their future, representing a long term investment. In Europe a subsidy or grant would have paid!!!

Talk to Graham Ogle and he will tell you that in every case where Farmax is used, the gain way exceeds the cost, and structural and management changes are made. The Sheep-for-Profit boys have made some huge gains with their clients, as have Cogent, Agtrac and others. What monitor or focus farm didn't make changes and ramp up production, efficiencies and profitability? AgResearch's Flock Master seems to have disappeared of the radar?

\section{So why so little uptake or interest on the part of the farmer?}

Bureaucratic business of comparable value and output spend $20+\%$ of their budget on administration and most of it they post out to a farmer or ask a volunteer to do it. Farmers spend $2 \%$ on administration if they are diligent and see it as a cost only. Farmers (and I generalise) are shocking record-keepers, the office a mess, financials are historic and only of any use to the tax man.

\section{How do we change this?}

Well I have a vision, with a carrot and stick approach! But if I told you I'd have to shoot you, which sums up the environment we work in. The tools are there, the technology is there, but the ability to deliver and recover costs is not.

To you research and development folk and scientists out there, if you want a fast uptake and adoption of your findings, tools and technologies, you need to promote and assist the 'on farm' measuring, monitoring and 
mentoring programmes.

And to farmers out there, you need to understand the value and progress that can be made as you are being left behind and will be swallowed up by the corporate farms that are running real-time offices that are being banked in a totally different way.

In terms of monitoring and measuring, I take you back to the Individual Animal Tracking. The tools are there and the technology is there. The justifications for these are many. The proponents talk of traceability and food safety, genetics, animal health and management gains. I believe the greatest gains will simply be in the ability to analyse and assess unit costs and margins all the way to the supermarket shelf, as other industries do. The transparencies will highlight opportunities for different classes of land. Marlborough's lower hill country and dry lands will have no stock in the summer from January to May. Some will winter transit stock (as other parts of the country have pugging issues), and others will have winter and early spring contracts to fill.

We need some leadership and drive at a national level for the national good.

Down on the farm lets keep it simple with our support teams. Have some sound rules by which to play, some long-term meaningful contracts and then it is our job to manage and understand the vagaries of the weather patterns. Support us with some tools to measure, manage and grow. Help us understand our issues and opportunities and let R \& D and science add value to all parties.

\section{So what next?}

Well change and adaptation will continue and the diversity will remain. Farmers like my good friend Doug Avery will continue to push the bar and strongly challenge us. The general populace will say "It's OK for him he's got a good farm"! or "It's all been tried before? You'll see."

Aging, (and I'm young in the demographics of farming) and slowing farmers like me will look for easier and lazier ways, as I wait for a son to return and re-ignite things, meanwhile pondering the $\$ 120,000$ bill for fertiliser at $\$ 600$ plus per tonne just to maintain the status quo, or do I grow less grass and have less stock and take a holiday in the Marlborough sun, all for the national good!!!?

Organic, really!!!

It's not up to me anymore, someone else will do it! 